American Journal of Pharmacology and Toxicology 6 (3): 88-95, 2011

ISSN 1557-4962

(C) 2011 Science Publications

\title{
Effect of Intrahippocampal $\gamma$ Aminobutyrate B Receptor on Pain Sensitivity during Estrous Cycle
}

\author{
Mahnaz Taherianfard and Rohollah Ghorbani \\ Department of Physiology, \\ School of Vet. Med., Shiraz University, Shiraz, Iran
}

\begin{abstract}
Problem statement: There is a relationship between sexual hormones and pain sensitivity and also a role for hippocampal $\mathrm{GABA}_{B}$ receptor in nociception. Therefore, the aim of the present investigation was to evaluate the effect of intrahippocampal injection of $\mathrm{GABA}_{\mathrm{B}}$ receptor agonist (baclofen) and $\mathrm{GABA}_{\mathrm{B}}$ receptor antagonist (CGP35348) on pain sensitivity during the estrous cycle. Approach: Forty eight adult female rats were used. The animals were divided into four groups: (1) Control; (2) Sham; (3) Baclofen 4.25 or $8.54 \mu \mathrm{g} \mathrm{rat}^{-1}$; (4) CGP35348 alone with doses 3 or $5 \mu \mathrm{g} \mathrm{rat}^{-1}$ and (5) CGP35348 3 or $5 \mu \mathrm{g} \mathrm{rat}^{-1}$ after $0.75 \mu \mathrm{L}$ of baclofen $8.54 \mu \mathrm{g} \mathrm{rat}^{-1}$. Data were analyzed by two ways ANOVA measuring. The level of significance was $\mathrm{p}<0.05$. Results: Our data showed that baclofen significantly decreased pain sensitivity in all stages of the estrous cycle, but this analgesic effect was higher during estrus. CGP35348 significantly increased pain sensitivity in all stages of the estrous cycle at $5 \mu \mathrm{g} \mathrm{rat}^{-1}$, but this hyperalgesic was least effective during the estrus stages of the estrous cycle. Administration of CGP35348 doses 3 or $5 \mu \mathrm{g} \mathrm{rat}{ }^{-1}$ after a high dose of baclofen significantly increased pain sensitivity; This hyperalgesic effect was greater than CGP35348 alone. Conclusion/Recommendations: According to our results, the $\mathrm{GABA}_{\mathrm{B}}$ receptor in the hippocampus can modulate pain sensitivity during the estrous cycle.
\end{abstract}

Key words: Estrous cycle, plasma concentrations, intrahippocampal injection, pain sensitivity, receptor agonist, female rats, baclofen significantly, hyperalgesic effect, modulate pain, nociceptive stimulation

\section{INTRODUCTION}

It is widely recognized that experience of pain is different in women and men. For example, women are generally considered to have a lower pain threshold than men in response to most forms of nociceptive stimulation (Wang et al., 2009). Evidence suggests that gonadal hormones can modulate sensitivity to nociceptive stimuli and opioid antinociception (Terner et al., 2005). The plasma concentrations of these hormones vary during the estrous cycle in rodents. On the other hand, the levels of enkephalin and dynorphins in the hippocampal granule cell mossy fiber pathway can regulate by ovarian steroids (Torres-Reverone et al., 2009). The hippocampal formation has long been implicated in learning and memory functions, as well as in affective motivational response to noxious stimulus (McKenna and Melzackm, 2001). An interaction of estradiol, important in the modulation of pain mechanisms, is that with the GABA system in the CNS, although the effects of estrogens on the GABA system are controversial (Aloisi and Bonifazi, 2006). The GABA action is due to the activation of GABA receptors including ionotropic type- $\mathrm{A}\left(\mathrm{GABA}_{\mathrm{A}}\right)$ and metabotropic type-B $\left(\mathrm{GABA}_{B}\right)$ (Kumamoto, 1997). Kirouac et al. (2004) showed that both the $\mathrm{GABA}_{\mathrm{A}}$ and $\mathrm{GABA}_{\mathrm{B}}$ receptor coexist in $\mathrm{A}$ delta and $\mathrm{C}$ afferent fibers that conduct pain stimuli (Kirouac et al., 2004). $\mathrm{GABA}_{\mathrm{B}}$ receptors can be located pre-synaptically, acting through inhibition of high voltage activated $\mathrm{Ca}^{2+}$ channels and causing suppression of neurotransmitter release (Wu and Saggau, 1997). Alternatively, they can also be postsynaptic, mediating slow and long lasting inhibitory postsynaptic potentials by activation of inwardly rectifying $\mathrm{K}^{+}$ channels, therefore inhibiting neuronal exitability (Bowery and Enna, 2000). Formalin-induced inflammatory pain increases the expression of heterodimeric $\mathrm{GABA}_{\mathrm{B}}$ receptor subunit mRNAs and protein in the dorsal horn of the rat spinal cord (Sands et al., 2003). In the brainstem, an increase in the 
expression of $\mathrm{GABA}_{\mathrm{B}}$ receptors was found in several nuclei after nociceptive stimulation (Pinto et al., 2003). In addition, in an acute pain test, baclofen microinjection into the nucleus rape Magnus and nucleus reticular is gigantocellularis pars alpha of the medulla, had either antinociceptive or hyperalgesic effects depending on the dose administered (Thomas et al., 1996). There is ample evidence from animal studies concerning a primary antinociceptive action of baclofen. It has been demonstrated that baclofen is antinociceptive in rats by using the hotplate and tailflick tests. Intraperitoneal injection of baclofen was also found to be antinociceptive to noxious thermal stimulation in cats and in formalin-injection tests in monkeys (Bowery, 2006). Baclofen has long been known to have antinociceptive activity in acute and chronic pain models (Hwang and Yaksh, 1997). On the other hand, pretreatment with estrogen can save $\mathrm{GABA}_{\mathrm{B}}$ receptor function, probably by neuroprotection of neurons containing postsynaptic $\mathrm{GABA}_{\mathrm{B}}$ receptors (Velisek and Veliskova, 2002). Noriega et al. (2010) reported that estrogen decreases the functional coupling of the mu-opioid and $\mathrm{GABA}_{\mathrm{B}}$ receptors to the inwardly rectifying $\mathrm{K}^{+}$channel, possibly through an action on the G-protein (Noriega et al., 2010). On the other hand progesterone and their metabolite have different effect on pain sensitivity (Frye and Duncan, 1994). Al-Dahan and Thalmann (1996) reported that progesterone variation during the estrous cycle could be responsible for one component of the regulation of $\mathrm{GABA}_{\mathrm{B}}$ receptors that occurs in neocortex during the estrous cycle of the rat (AlDahan and Thalmann 1996). Therefore, the aim of the present study was to investigate the effect of baclofen $\left(\mathrm{GABA}_{\mathrm{B}}\right.$ agonist) and CGP35348 (GABA $\mathrm{B}_{\mathrm{B}}$ antagonist) on pain sensitivity during the estrous cycle in rats; it means that we examine the effect of natural change of ovarian hormone on pain sensitivity.

\section{MATERIALS AND METHODS}

Animals: Forty eight female Sprague Dawley rats weighing 200-220g were used. Food and water were made available ad libitum. Rats were housed under a $12 \mathrm{~h}$ light/dark (light on at $6 \mathrm{am}$ ) and controlled temperature $\left(20 \pm 4^{\circ} \mathrm{C}\right)$ condition. Animals were divided into five groups: (1) control group (intact animal, $\mathrm{n}=$ 6); (2) sham (received $0.75 \mu \mathrm{L}$ of Artificial Cerebrospinal Fluids (ACSF), $n=6$ ); (3) experimental 1 (received $0.75 \mu \mathrm{L}$ of baclofen 4.25 or $8.54 \mu \mathrm{g} \mathrm{rat}^{-1}$, $\mathrm{n}$ = 12); (4) experimental 2 (received $0.75 \mu \mathrm{L}$ of CGP35348 3 or $5 \mu \mathrm{g} \mathrm{rat}^{-1}, \mathrm{n}=12$ ) and (5) experimental 3 (received $0.75 \mu \mathrm{L}$ of CGP35348 3 or 5 $\mu \mathrm{g} \mathrm{rat}^{-1} 15 \mathrm{~min}$ after 0.75 baclofen $8.54 \mu \mathrm{g} \mathrm{rat}^{-1}, \mathrm{n}=$
12). In all animals, the formalin test was performed in all stages of the estrous cycle. Each group consists of 5 rats and every rat was received formalin test 4 times; the duration between the tests was 4-5 days.

Determination of the estrous cycle stage in female rats: Before the experiment, different stages of the estrous cycle were detected by microscopic examination of vaginal smear based on the relative frequency of leukocyte, cornfield and nucleated epithelial cells (Eldridge et al., 1999).

Formalin test: Five min after injection of ACSF or drugs, $50 \mu \mathrm{L}$ of $2.5 \%$ formalin solution was injected subcutaneously into the plantar surface of right hind paw using a 30 gauge needle. A Pain score was determined for each 5 min block (each block consisted of a mean of 20 records in every $15 \mathrm{sec}$ ) during $60 \mathrm{~min}$, by measuring the number of each of the following four behavioral categories: 0 , the injected paw is not favored; (1) the injected paw has little or no weight on it; (2) the injected paw is elevated and is not in contact with any surface; (3) the injected paw is licked, bitten or shaken (Abbott et al., 1995). The records of the first $10 \mathrm{~min}$ were considered as phase 1 of the formalin test, while the records after 10 min were considered as phase 2 of the formalin test.

Surgery: The rats were anesthetized with an IP injection of ketamine $35 \mathrm{mg} \mathrm{\textrm {kg } ^ { 1 }}$ and xylazine $5 \mathrm{mg} \mathrm{\textrm {kg } ^ { 1 }}$ and, after mounting in a stereotaxic instrument (Stoelting, USA) a cannula (23 gauge) was implanted unilaterally at the right hippocampus (AP: $3.5 \mathrm{~mm}$ behind the bregma, lateral: $3.1 \mathrm{~mm}$ and vertical: 4.5 $\mathrm{mm}$ from cerebral cortex). Two screws were placed in the skull and each cannula was anchored into place with dental cement poured around the outer cannula and screws. A stainless steel extending just beyond the tip of the cannula was inserted and left in place until injection. The animals were allowed to recover for at least 7 days after surgery (Soignier et al., 2000). Rats were given a lethal dose of ether following testing. The microinjection site was marked by injecting of cresyl violet $(0.2 \mu \mathrm{L})$ into the hippocampus. The brain was removed, placed in formalin $(10 \%)$ and a coronal section was prepared to determine correction of surgery. This protocol has been approved by our animal use committee.

Data analysis: For analysis of data SPSS program were used. Data were analyzed by one way Analysis Of Variance (ANOVA). Tukey test was performed as posthoc. Significant value was $\mathrm{p}<0.05$. Data were considered in results as mean \pm SEM. 


\section{RESULTS}

Effect of intrahippocampal injection of baclofen on
pain sensitivity during estrous cycle: Intrahippocampal injection of two doses of baclofen in phase 1 of the formalin test has no effect on pain score in postures $[\mathrm{F}(3)=0.4, p=0.754)$, but significantly decreased pain sensitivity during the estrus $[\mathrm{F}(3)=$ $14.5, \mathrm{P}=0.000)$, met estrus $[\mathrm{F}(3)=10.6, \mathrm{p}=0.000$ ) and diestrus $[\mathrm{F}(3)=5.5, \mathrm{p}=0.006)$ stages of the estrous cycle (Fig. 1). Intrahippocampal injection of baclofen $\left(8.54 \mu \mathrm{g} \mathrm{rat}^{-1}\right)$ in phase 2 of the formalin test significantly $(\mathrm{p}<0.05)$ decreased pain sensitivity during proestrus $[\mathrm{F}(3)=5.78, \mathrm{P}=0.005)$, estrus $[\mathrm{F}$ $(3)=8.8, \mathrm{P}=0.001)$ and metestrus $[\mathrm{F}(3)=15, \mathrm{P}=$ $0.000)$ and diestrus $[\mathrm{F}(3)=14.6, \mathrm{P}=0.000)$ stages of the estrous cycle (Fig. 1).

Analgesic effect of baclofen 4.27 and $8.54 \mathrm{ug} \mathrm{rat}^{-1}$ in phase 1 of formalin test was significantly higher during estrus $[\mathrm{F}(3)=13.9, \mathrm{P}=0.001)$ in the phases 2 of the formalin test the similar effect were shown [F (3) $=9.33, \mathrm{p}=0.001)($ Fig. 1).

Effect of intrahippocampal injection of CGP35348 on pain sensitivity during estrous cycle:

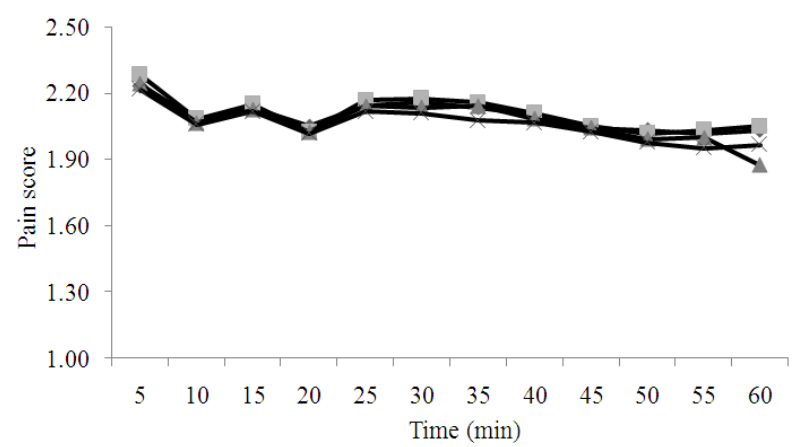

(a)

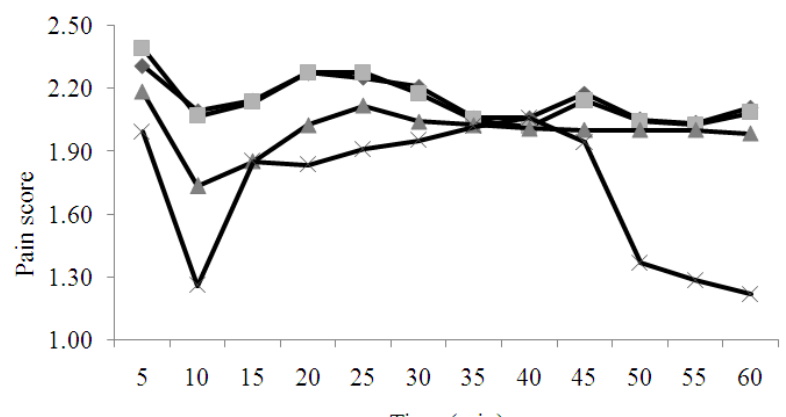

(c)
Intrahippocampal injection of CGP35348 (5 $\left.\mu \mathrm{g} \mathrm{rat}^{-1}\right)$ in phase 1 of the formalin test significantly $(\mathrm{p}<0.05)$ increased pain sensitivity during the proestrus $[\mathrm{F}(3)=$ $12, \mathrm{p}=0.000)$ and estrus $[\mathrm{F}(3)=3.4, \mathrm{P}=0.038)$ stages of the estrous cycle, but it has no significant effect during metestrus $[\mathrm{F}(3)=0.6, \mathrm{p}=0.602)$ and diestrus $[\mathrm{F}(3)=1.6, p=0.22)$ (Fig. 2). Intrahippocampal injection of CGP35348 (5 $\left.\mu \mathrm{g} \mathrm{rat}^{-1}\right)$ in phase 2 of the formalin test significantly $(\mathrm{p}<0.05)$ increased pain sensitivity during the proestrus $[\mathrm{F}(3)=$ $3.2, p=0.047)$ and estrus $[\mathrm{F}(3)=4.3, \mathrm{p}=0.017)$ stages of the estrous cycle, but it has no significant effect during metestrus $[\mathrm{F}(3)=2.2, \mathrm{p}=0.12)$ and diestrus $[F(3)=1.1, p=0.373$ ) (Fig. 2). Also, there was a significant $(\mathrm{p}<0.05)$ difference between the two doses of CGP35348 (Fig. 1).

Hyperalgesic effect of CGP35348 ( 3 and $5 \mathrm{ug} \mathrm{rat}^{-1}$ ) was significantly $(\mathrm{p}<0.05)$ higher during the proestrus stage of the estrous cycle in phase 1 of formalin test $[\mathrm{F}$ (3) $=11.7, p=0.000$ ). Hyperalgesic effect of CGP35348 $\left(3\right.$ and $\left.5 \mathrm{ug} \mathrm{rat}^{-1}\right)$ was significantly $(\mathrm{p}<0.05)$ higher during the metestrus stage of the estrous cycle in phase 2 of formalin test $[\mathrm{F}(3)=14.2, \mathrm{p}=0.000)$.

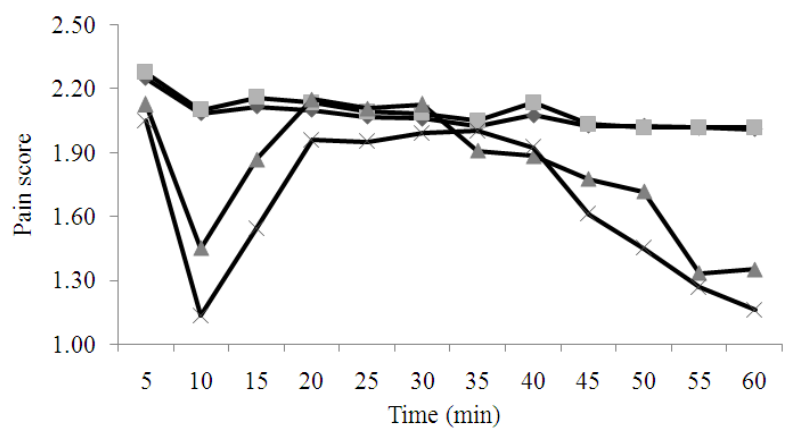

(b)

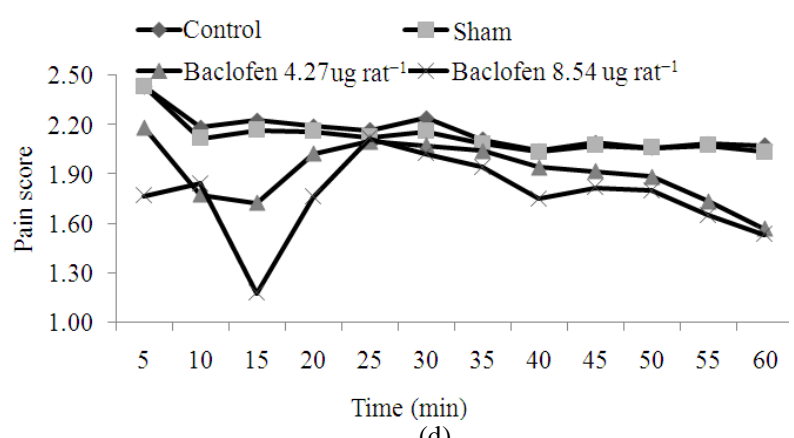

(d)

Fig. 1: Effect of intrahippocampal injection of baclofen on mean of pain score during estrous cycle (A); proestrus, (B) estrus, (C) metestrus and (D) diestrus, $\mathrm{N}=6$ in each group 
Am. J. Pharm. \& Toxicol., 6 (3): 88-95, 2011
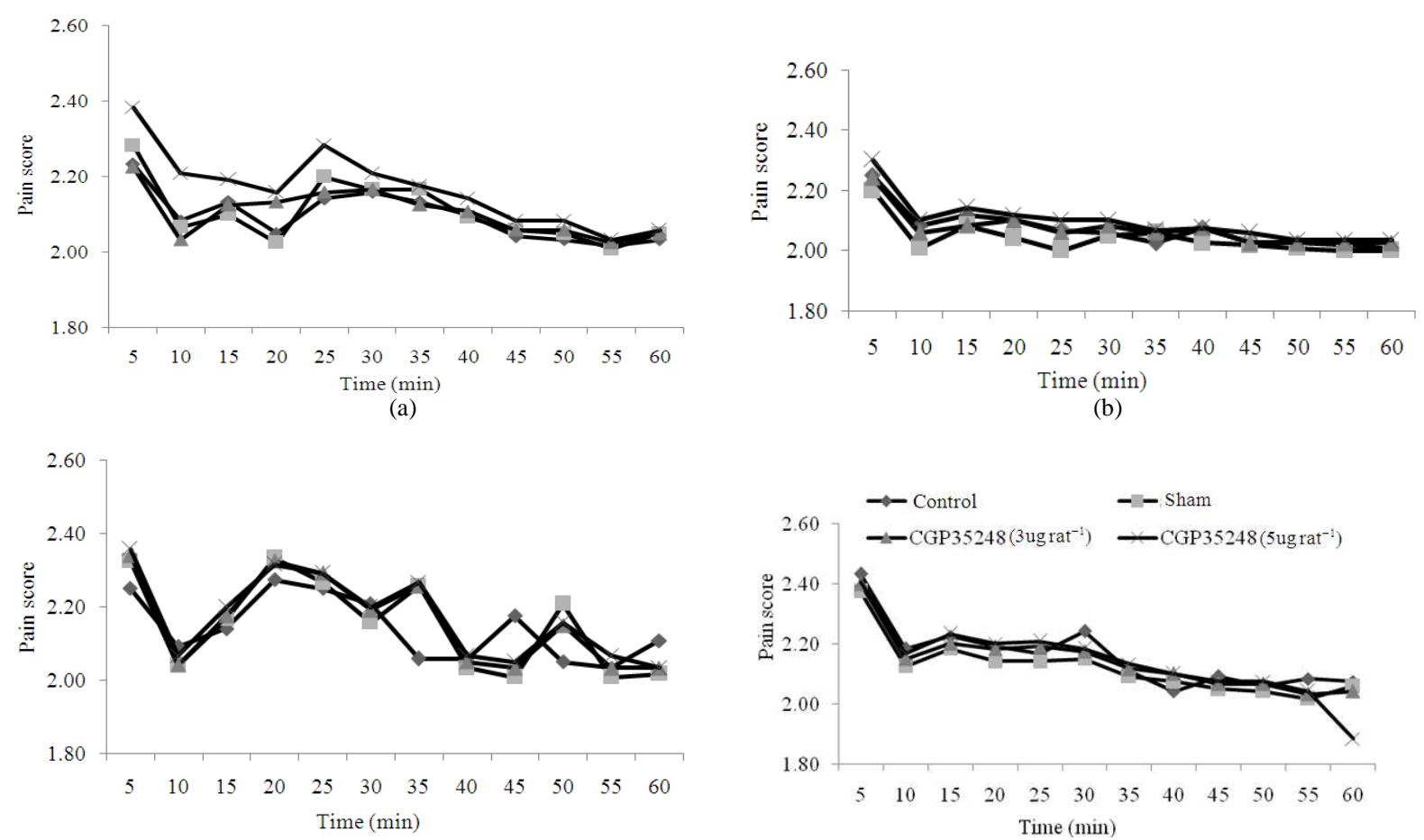

(c)

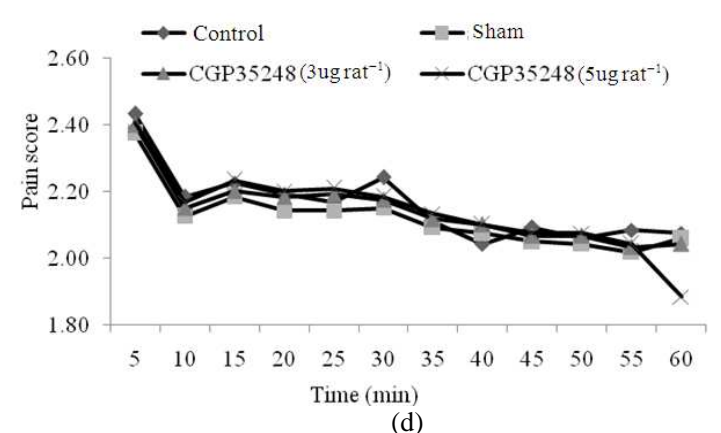

Fig. 2: Effect of intrahippocampal injection of CGP35348 on mean of pain score during estrous cycle; (A) proestrus, (B) estrus, (C) metestrus and (D) diestrus, $\mathrm{N}=6$ in each group

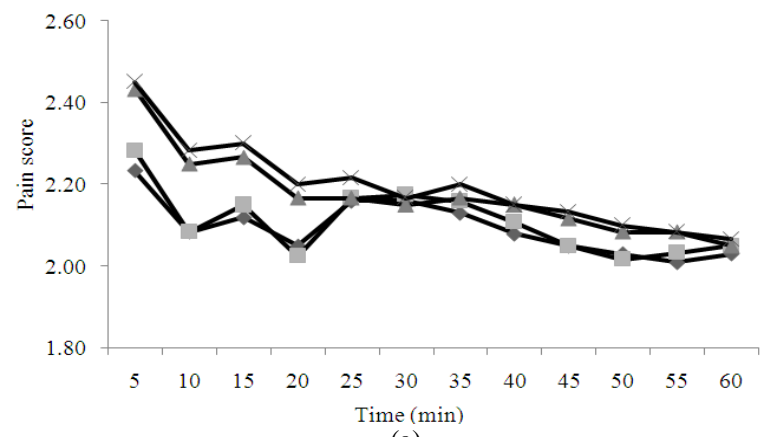

(a)

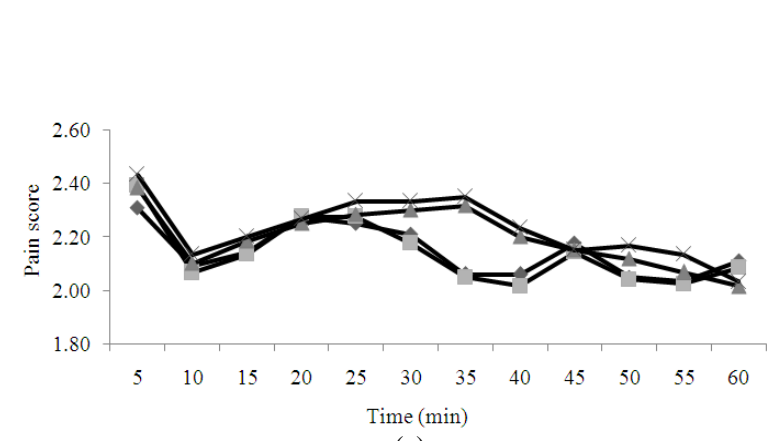

(c)

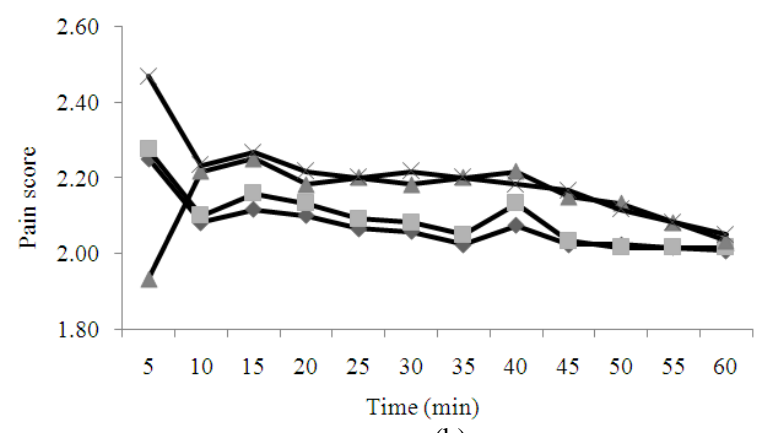

(b)

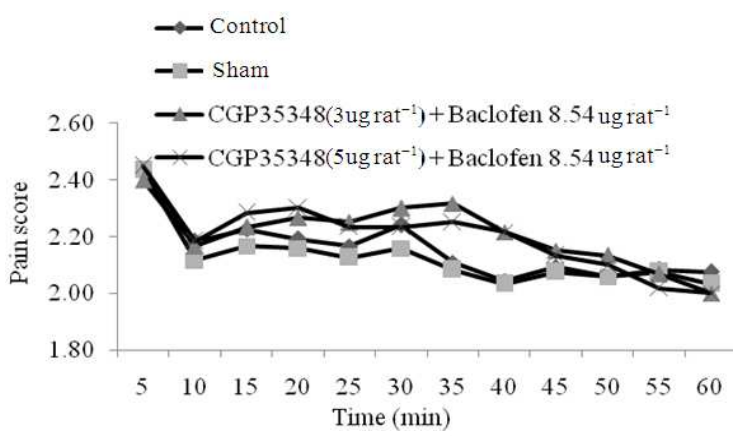

(d)

Fig. 3: Effect of intrahippocampal injection of baclofen pretreatment by CGP35348 on mean of pain score during estrous cycle; (A) proestrus, (B) estrus, (C) metestrus and (D) diestrus, $\mathrm{N}=6$ in each group 
Am. J. Pharm. \& Toxicol., 6 (3): 88-95, 2011

Effect of intrahippocampal injection of CGP35348 + baclofen on pain sensitivity during estrous cycle: The simultaneous intrahippocampal injection of CGP35348 (3 and $\left.5 \mu \mathrm{g} \mathrm{rat}^{-1}\right)+$ baclofen $\left(8.54 \mu \mathrm{g} \mathrm{rat}^{-1}\right)$ in phase 1 of the formalin test, significantly $(\mathrm{p}<0.05)$ increased pain sensitivity only in the proestrus $[\mathrm{F}(3)=$ $36.6, \mathrm{p}=0.000$ ) stage of the estrous cycle, while simultaneous intrahippocampal injection of CGP35348 (3 and $\left.5 \mu \mathrm{g} \mathrm{rat}^{-1}\right)+$ baclofen $\left(8.54 \mu \mathrm{g} \mathrm{rat}^{-1}\right)$ in phase 1 of the formalin test, had no significant effect during estrus $[\mathrm{F}(3)=1.75, \mathrm{p}=0.2)$, metestrus $[\mathrm{F}(3)=5.2, \mathrm{p}=$ $0.078)$ and diestrus $[F(3)=0.8, p=0.5)$ stage of estrous cycle. Simultaneous intrahippocampal injection of CGP35348 (3 and $\left.5 \mu \mathrm{g} \mathrm{rat}^{-1}\right)+$ baclofen $(8.54 \mu \mathrm{g}$ $\left.\mathrm{rat}^{-1}\right)$ in phase 2 of the formalin test, significantly $(\mathrm{p}<0.05)$ increased pain sensitivity in proestrus $[\mathrm{F}(3)=$ 9.76, $\mathrm{p}=0.001)$, estrus $[\mathrm{F}(3)=7.17, \mathrm{P}=0.004)$ and metestrus $[\mathrm{F}(3)=14.3, \mathrm{p}=0.000)$ and diestrus $[\mathrm{F}(3)=$ 29, $p=0.000$ ) stages of the estrous cycle (Fig. 3).

Simultaneous intrahippocampal injection of CGP35348 (3 and $\left.5 \mu \mathrm{g} \mathrm{rat}^{-1}\right)+$ baclofen $\left(8.54 \mu \mathrm{g} \mathrm{rat}^{-1}\right)$ induced hyperalgesia was greater than the administration of CGP35348 ( 3 and $5 \mu \mathrm{g} \mathrm{rat}^{-1}$ ) alone.

The hyperalgesic effect of CGP35348 (3 and $5 \mathrm{ug}$ rat $^{-1}$ ) after baclofen $8.54 \mathrm{ug} \mathrm{rat}^{-1}$ was significantly higher during metestrus and diestrus than the proestrus and estrus $[F(3)=7.28, p=0.011)$ stage of the estrous cycle in phase 2 of formalin test. In phase 1 of formalin test, there is no significant difference between four phases of estrous cycle.

\section{DISCUSSION}

The rat formalin test is a reliable animal model of pain induced by acute tissue injury (Tjolsen et al., 1992). Moreover, the formalin-induced nociceptive behaviors elicited in animals are quantifiable and show two phases: an early phase (acute pain) that starts immediately after formalin injection and lasts approximately $5 \mathrm{~min}$ and a late phase which begins $15-$ $20 \mathrm{~min}$ after the formalin injection lasting 20-40 min. This last phase, also named tonic or chronic phase, is dependent on local inflammation and/or prolonged changes in the CNS (Tjolsen et al., 1992). Between these two phases there is a period, the interphase, in which the animals display hardly any pain-related behaviors (Tjolsen et al., 1992). Both the first and the second phase of the formalin test are accompanied by an increase in the activity of $\mathrm{A} \delta$ and C-fiber primary afferents.

The present study showed that baclofen injection in hippocampus ipsilateral to the formalin injected paw decreases pain sensitivity in all stages of the estrous cycle, similar to the effect of intracerebroventicular injection of baclofen in our previous study (Taherianfard et al., 2009). Potes et al. (2006) reported that baclofen injection in the ventrobasal complex of the thalamus contralateral to the formalin-injected paw decreased all nociceptive behaviors displayed by the rats in the formalin test in a dose-dependent manner, indicating an antinociceptive effect of this selective $\mathrm{GABA}_{\mathrm{B}}$ agonist (Potes et al., 2006). Brusberg et al. (2009) demonstrated that systemic activation of $\mathrm{GABA}_{\mathrm{B}}$ receptors in conscious rats, either by the orthosteric agonist baclofen or, to a lesser extent, by the positive allosteric modulator CGP7930, reduces pseudo-affective responses to noxious colorectal distension in rats (Brusberg et al., 2009). Intrathecal administration of the $\mathrm{GABA}_{B}$ receptor agonist baclofen produced a dose-dependent decrease in response to formalin injected hind paw. This antinociceptive effect of baclofen was antagonized by pretreatment with $\mathrm{GABA}_{\mathrm{B}}$ receptor antagonist saclofen (Naderi et al., 2005). Patel et al. (2001) reported that L-baclofen has marked antihyperalgesic activity in a model of neuropathic pain in the rat. The effect of baclofen was blocked by the selective $\mathrm{GABA}_{B}$ receptor antagonist CGP56433A (Patel et al., 2001). Yang et al. (2003) demonstrated that the activation of $\mathrm{GABA}_{B}$ receptors by baclofen in the ventrolateral periaqueductal gray neurons has a threefold action: 1hyperpolarization of periaqueductal gray neurons (postsynaptic inhibition), 2- decrease in the release of L-glutamate nerve terminals to periaqueductal gray neurons (presynaptic inhibition) and 3- decrease in the release of GABA from nerve terminals to periaqueductal gray neurons (presynaptic inhibition) (Yang et al., 2003).

On the other hand, pain stimulus leads to changes in the expression of $\mathrm{GABA}_{\mathrm{B}}$ receptors. The results of Castro et al. (2006) point to differences in the expression of $\mathrm{GABA}_{\mathrm{B}}$ receptors in spinofugal pathways targeting pronociceptive and antinociceptive regions. McCarson et al. (2005) revealed that both thermal and mechanical withdrawal thresholds are lowered significantly in rats 7 days following a partial ligation of the sciatic nerve, while this nerve damage increases the gene expression of both the $\mathrm{GABA}_{\mathrm{B}(1 \mathrm{a})}$ and $\mathrm{GABA}_{\mathrm{B}(2)}$ in the ipsilateral lumbar spinal cord (McCarson et al., 2005). Formalin induced inflammatory pain increases the levels of mRNA and protein for $\mathrm{GABA}_{\mathrm{B}(1 \mathrm{a})}$ and $\mathrm{GABA}_{\mathrm{B}(2)}$ in the dorsal horn of the rat spinal cord (Sands et al., 2004).

In the present study, baclofen has the highest analgesic action in the estrus stage of the estrous cycle, whereas in the other study, the analgesic effect of 
intracerbrospinal injection of the baclofen was higher during metestrus and diestrus (Taherianfard et al., 2009). It seems that site of injection is important and this difference may be related to the estradiol receptor or $\mathrm{GABA}_{\mathrm{B}}$ receptor distribution in different brain locations. The metabotropic $\mathrm{GABA}_{\mathrm{B}}$ receptors mediate slow synaptic inhibition and consist of heterodimers of B1 and B2 subunits (Bettler et al., 2004) which share structural homology with class-III G protein-coupled receptors (Binet et al., 2004). The only known molecular diversity of the $\mathrm{GABA}_{\mathrm{B}}$ receptors arises from two GABA B1 $_{1}$ isoforms (Kaupmann et al., 1998). Noriega et al. (2010) reported that $17 \beta$-estradiol and $17 \beta$-estradiol + progesterone led to the up regulation of the gene encoding the $\mathrm{GABA}_{\mathrm{B}}$ receptor subunit 1 in the amygdala (Noriega et al., 2010).

Administration of CGP35348 has a paradoxical effect on pain response. In the present study, CGP35348 injection in hippocampus ipsilateral to the formalin injected paw alone in two doses induced hyperalesia in the proestrus and estrus stage of the estrous cycle, but not in the metestrus and diestrus stage of the cycle, while pretreatment of CGP35348 in two doses before baclofen induced hyperalgesia in all stages of the estrous cycle. Poets et al. (2006) showed that administration of CGP35348 induced a decrease of pain related activities in both phases of the formalin test, as baclofen did (Potes et al., 2006). However, there are other studies that have already reported similar effects of baclofen or of CGP35348 administration upon the nociceptive behavior of the animals. In fact, the intracerebrospinal administration of different doses of baclofen or of CGP35348 induced by themselves antinociception in both non-ligated and ligated mice subjected to the hot plate test (Zarrindast et al., 2000). Ataka et al. (2000) revealed that baclofen $(1 \mu \mathrm{M})$ reduces the amplitude of EPSPs, which are monosynaptically evoked in substantia gelatinosa neurons of spinal cord slices by stimulating primary afferent fibers. This action of baclofen was more effective on EPSC than on A $\delta$ fiber EPSC, while CGP35348 antagonized both actions (Ataka et al., 2000). There is evidence that the $\mathrm{GABA}_{\mathrm{B}}$ receptor antagonist CGP35024 reverses mechanical hyperalgesia in one model of neuropathic pain in the rat, with concomitant inhibitory activity on nociceptive transmission in the spinal cord (Patel et al., 2001).

\section{CONCLUSION}

In the present study, the hyperalgesic effect of CGP35348 alone is highest during the proestrus stage of the estrous cycle; while the hyperalgesic effect of pretreatment of CGP35348 in two doses before baclofen in the metestrus and diestrus stages of the estrus cycle is more than in the proestrus and estrus stages of the estrus cycle. Intracerebrospinal injection of CGP35348 had a similar effect (Taherianfard et al., 2009). There is evidence that GABAergic mediation of opioid effects is a widespread phenomenon and occurs throughout most regions of the CNS. Kalyuzhny and Wessenorf (1999) observed a colocalization between hippocampal $\mu$-opioid receptors in CA1, CA3 and dentate gyrus in rats. The localization of the $\mu$-opioid receptor on the GABAergic neuron suggests that these receptors, when activated, can directly control the hippocampal GABAergic neurons activity (Kalyuzhny and Wessendorf 1997; 1999). Torres-Reverone et al. (2009) demonstrated that ovarian steroids alter the trafficking of mu opioid receptors within subpopulations of hippocampal GABAergic interneuron (Torres-Reverone et al., 2009). Al-Dahan and Thalmann (1996) results indicated that progesterone variation during the estrous cycle could be responsible for a component of the regulation of $\mathrm{GABA}_{\mathrm{B}}$ receptors that occurs in the neocortex during the estrous cycle of rat (Al-Dahan and Thalmann, 1996).

Role of the funding source: This study was supported by the Vice-Chancellery of Research of Shiraz University. The Vice-Chancellery of Research of Shiraz University had no further role in the study design; in the collection, analysis and interpretation of data; in the writing of the report; and in the decision to submit the paper for publication.

Conflict of interest: All the authors can confirm that there is no financial or other relationship that would cause a conflict of interest.

\section{ACKNOWLEDGMENTS}

This study was financially supported by The ViceChancellery of Research of Shiraz University.

\section{REFERENCES}

Abbott, F.V., K.B.J. Franklin and R.F. Westbrook, 1995. The formalin test: Scoring properties of the first and second phases of the pain response in rats. Pain, 6: 91-2. DOI: 10.1016/0304-3959(94)00095-V

Al-Dahan, M.I. and R.H. Thalmann, 1996. Progesterone regulates gamma-Aminobutyric Acid $\mathrm{B}\left(\mathrm{GABA}_{\mathrm{B}}\right)$ receptors in the neocortex of female rats. Brain Res., 727: 40-48. DOI: 10.1016/00068993(96)00338-1 
Aloisi, A.M. and M. Bonifazi, 2006. Sex hormones, central nervous system and pain. Horm. Behav., 50: 1-7. DOI: 10.1016/j.yhbeh.2005.12.002

Ataka, T., E. Kumamoto, K. Shimoji and M. Yoshimura, 2000. Baclofen inhibits more effectively C-afferent than Adelta-afferent glutamatergic transmission in substantia gelatinosa neurons of adult rat spinal cord slices. Pain, 86: 273-282. PMID: 10812257

Bettler, B., K. Kaupmann, J. Mosbacher and M. Gassmann, 2004. Molecular structure and physiological functions of $\mathrm{GABA}_{\mathrm{B}}$ receptors. Physiol. Rev., 84: 835-867. DOI: 10.1152/physrev.00036.2003

Binet, V., C. Brajon, L.L. Corre, F. Acher and J.P. Pin et al., 2004. The heptahelical domain of $\mathrm{GABA}_{\mathrm{B} 2}$ is activated directly by $\mathrm{CGP}_{7930}$, a positive allosteric modulator of the $\mathrm{GABA}_{\mathrm{B}}$ receptor. J. Biol. Chem., 279: 29085-29091. DOI 10.1074/jbc.M400930200

Bowery, N.G. and S.J. Enna, 2000. gammaaminobutyric acid(B) receptors: first of the functional metabotropic heterodimers. J. Pharmacol. Exp. Ther., 292: 2-7. PMID: 10604925

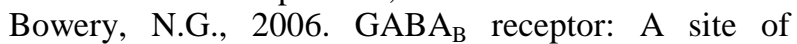
therapeutic benefit. Curr. Opin. Pharmacol., 6: 3743. DOI: 10.1016/j.coph.2005.10.002

Brusberg, M., A. Ravnefjord, R. Martinsson, H. Larsson and V. Martinez et al., 2009. The $\mathrm{GABA}_{\mathrm{B}}$ receptor agonist, baclofen, and the positive allosteric modulator, $\mathrm{CGP}_{7930}$, inhibit visceral painrelated responses to colorectal distension in rats. Neuropharmacology, 56: 362-367. DOI: 10.1016/j.neuropharm.2008.09.006

Castro, A.R., C. Morgado, D. Lima and I. Tavares, 2006. Differential expression of $\mathrm{NK} 1$ and $\mathrm{GABA}_{\mathrm{B}}$ receptors in spinal neurones projecting to antinociceptive or pronociceptive medullary centres. Brain Res. Bull., 69: 266-275. DOI: 10.1016/j.brainresbull.2005.12.004

Eldridge, J.C., L.T. Wetzel and L. Tyrey, 1999. Estrous cycle patterns of Sprague-Dawley rats during acute and chronic atrazine administration. Reprod Toxicol., 13: 491-499. DOI: 10.1016/S08906238(99)00056-8

Frye, C.A. and J.E. Duncan, 1994. Progesterone metabolites, effective at the $\mathrm{GABA}_{\mathrm{A}}$ receptor complex, attenuate pain sensitivity in rats. Brain Res., 643: 194-203. DOI: 10.1016/00068993(94)90025-6

Hwang, J.H. and T.L. Yaksh, 1997. The effect of spinal GABA receptor agonists on tactile allodynia in a surgically-induced neuropathic pain model in the rat. Pain, 70: 15-22. DOI: 10.1016/S03043959(96)03249-6
Kalyuzhny, A.E. and M.W. Wessendorf, 1997. CNS GABA neurons express the mu-opioid receptor: immunocytochemical studies. Neuroreport, 8: 3367-3372. PMID: 9351674

Kalyuzhny, A.E. and M.W. Wessendorf, 1999. Serotonergic and GABAergic neurons in the medial rostral ventral medulla express $\kappa$-opioid receptor immunoreactivity. Neuroscience, 90: 229234. DOI: 10.1016/S0306-4522(98)00376-5

Kaupmann, K., B. Malitschek, V. Schuler, J. Heid and W. Froestl et al,. 1998. GABA B $_{\text {receptor subtypes }}$ assemble into functional heteromeric complexes. Nature, 396: 683-687.

Kirouac, G.J., S. Li and G. Mabrouk, 2004. GABAergic projection from the ventral tegmental area and substantia nigra to the periaqueductal gray region and the dorsal raphe nucleus. J. Comp. Neurol., 469: 170-184. DOI: 10.1002/cne. 11005

Kumamoto, E., 1997. The pharmacology of amino-acid responses in septal neurons. Prog. Neurobiol., 52: 97-259. DOI: 10.1016/S0301-0082(97)00016-6

McCarson, K.E., A. Ralya, S.A. Reisman and S.J. Enna. 2005. Amitriptyline prevents thermal hyperalgesia and modifications in rat spinal cord $\mathrm{GABA}_{\mathrm{B}}$ receptor expression and function in an animal model of neuropathic pain. Biochem. Pharmacol., 71: 196-202. DOI: 10.1016/j.bcp.2005.10.026

McKenna, J.E. and R. Melzack, 2001. Blocking NMDA receptors in the hippocampal dentate gyrus with AP5 produces analgesia in the formalin pain test. Exp. Neurol., 172: 92-99. DOI: 10.1006/exnr.2001.7777

Naderi, N., B. Shafaghi, M.J. Khodayar and M.R. Zarindast, 2005. Interaction between gammaaminobutyric acid GABAB and cannabinoid CB1 receptors in spinal pain pathways in rat. Eur. J. Pharmacol., 514: 159-164. PMID: 15910802

Noriega, N.C., D.H. Eghlidi, V.T. Garyfallou, S.G. Kohama and S.G. Kryger et al., 2010. Influence of 17beta-estradiol and progesterone on GABAergic gene expression in the arcuate nucleus, amygdala and hippocampus of the rhesus macaque. Brain Res., 1307: 28-42. PMID: 19833106

Patel, S., S. Naeem, A. Kesingland, W. Froestl and M. Capogna et al., 2001. The effects of $\mathrm{GABA}_{\mathrm{B}}$ agonists and gabapentin on mechanical hyperalgesia in models of neuropathic and inflammatory pain in the rat. Pain, 90: 217-226. DOI: 10.1016/S0304-3959(00)00404-8

Pinto, M., D. Lima, J. Castro-Lopes and I. Tavares, 2003. Noxious-evoked c-fos expression in brainstem neurons immunoreactive for $\mathrm{GABAB}$, mu-opioid and NK-1 receptors. Eur. J. Neurosci., 17: 1393-1402. PMID: 12713642 
Potes, C.S., F.L. Neto and A.R. Castro-Lopes, 2006. Inhibition of pain behavior by $\mathrm{GABA}_{\mathrm{B}}$ receptors in the thalamic ventrobasal complex: Effect on normal rats subjected to the formalin test of nociception. Brain Res., 1115: 37-47. DOI: 10.1016/j.brainres.2006.07.089

Sands, S.A., K.E. McCarson and S.J. Enna, 2003. Differential regulation of $\mathrm{GABA}_{\mathrm{B}}$ receptor subunit expression and function. J. Pharmacol. Exp. Ther., 305: 191-196. DOI: 10.1124/jpet.102.046342

Sands, S.A., K.E. McCarson and S.J. Enna, 2004. Relationship between the antinociceptive response to desipramine and changes in $\mathrm{GABA}_{\mathrm{B}}$ receptor function and subunit expression in the dorsal horn of the rat spinal cord. Biochem. Pharmacol., 67: 743-749. DOI: 10.1016/j.bcp.2003.10.008

Soignier, R.D., A.L. Vaccarino, A.M. Brennan, A.J. Kastin and J.E. Zadina, 2000. Analgesic effects of endomorphin-1 and endomorphin-2 in the formalin test in mice. Life Sci., 67: 907-912. DOI: 10.1016/S0024-3205(00)00689-5

Taherianfard, M., M. Fazeli, F. Saremi and H. Bozorgi, 2009. Effect of intRAcerebroventicular injection of baclofen and CGP35348 on pain sensitivity during estrous cycle. Physiol. Pharmacol., 13: 88-97.

Terner, J.M., L.M. Lomas and M.J. Picker, 2005. Influence of estrous cycle and gonadal hormone depletion on nociception and opioid antinociception in female rats of four strains. J. Pain, 6: 372-383. DOI: 10.1016/j.jpain.2005.01.354

Thomas, D.A., I.M. Navarrete, B.A. Graham, M.K. McGowan and D.L. Hammond, 1996. Antinociception produced by systemic R(+)-baclofen hydrochloride is attenuated by CGP 35348 administered to the spinal cord or ventromedial medulla of rats. Brain Res., 718: 129-137. DOI: 10.1016/0006-8993(96)00100-X
Tjolsen, A., O.G. Berge, S. Hunskaar, J.H. Rosland and K. Hole, 1992. The formalin test: An evaluation of the method. Pain, 51: 5-7. DOI: 10.1016/03043959(92)90003-T

Torres-Reverone, A., T.J. Williams, J.D. Chapleau, E.M. Waters and B.S. McEwen et al., 2009. Ovarian steroids alter mu opioid receptor trafficking in hippocampal parvalbumin GABAergic interneurons. Exp. Neurol., 219: 319-327. DOI: 10.1016/j.expneurol.2009.06.001

Velisek, L. and J. Veliskova, 2002. Estrogen treatment protects $\mathrm{GABA}_{\mathrm{B}}$ inhibition in the dentate gyrus of female rats after kainic acid-induced status epilepticus. Epilepsia, 43: 146-151. DOI: 10.1046/j.1528-1157.43.s.5.3.x

Wang, Z., Y. Guo, S. Bradesi, J.S. Labus and J.M. Maarek et al., 2009. Sex differences in functional brain activation during noxious visceral stimulation in rats. Pain, 145: 120-128. DOI: 10.1016/j.pain.2009.05.025

Wu, L.G. and P. Saggau, 1997. Presynaptic inhibition of elicited neurotransmitter release. Trends Neurosci., 20: 204-212. DOI: 10.1016/S01662236(96)01015-6

Yang, K., H. Furue, E. Kumamoto, Y. X. Dong and M. Yoshimura, 2003. Pre- and postsynaptic inhibition mediated by $\mathrm{GABA}_{\mathrm{B}}$ receptors in rat ventrolateral periaqueductal gray neurons. Biochem. Biophys. Res. Commun., 302: 233-237. DOI: 10.1016/S0006-291X(03)00156-6

Zarrindast, M., S. Valizadeh and M. Sahebgharani, 2000. $\mathrm{GABA}_{\mathrm{B}}$ receptor mechanism and imipramineinduced antinociception in ligated and non-ligated mice. Eur. J. Pharmacol., 407: 65-72. DOI: 10.1016/S0014-2999(00)00648-8 